\title{
FORMS AND RANGE OF ACTIONS SUPPORTING DEVELOPMENT AMONG DISABLED CHILDREN AND YOUTH CONDUCTED BY PUBLIC SCHOOLS, INTEGRATED AND SPECIAL NEEDS CLASSES
}

\begin{abstract}
Both an able bodied student and his disabled peer reveals as an integral and unique individual with a fixed development potential. The development itself is a complex, multi-aspect and long term process which means that it is not easy to be defined in a straightforward way. Regardless of assumptions made about educational solutions, which further assume complete inclusion of students with disabilities or co-existence of special needs education, there is a demand towards individuality of education, which determines such an approach towards the student so that previously chosen carrier path could be potentially relevant to his individual needs. The article presents a complexity while supporting disabled students in their school education and it is aimed is to establish, based on the interviews with teachers employed at schools with integrated classes, the nature and basic forms of actions undertaken in the area of supporting general growth of disabled students and oriented towards their versatile development.
\end{abstract}

KeYWORDS: disability, support, development, children, youth, public school, integration classes

\section{INTRODUCTION}

Disability reveals as one of the major problems in contemporary world. It results from its global occurrence among societies but also consequences which arise within individual and social meaning. The number of children with disabilities is constantly growing each year. Such an increase in number 
demands to pay closer attention to the problematic issue and search for optimal solutions. In a particular way it refers to the sphere of a widely understood education. The character of disability, its occurrence and spread of organic, psychological and social effects influences both the life of a disabled child and his family.

As a result of lack of acceptance, disabled people experience loneliness and gradual exclusion from their social life. The consequence of such situation is low self-esteem, lack of motivation towards functioning, which results in scarcity of possibilities to accomplish life aims. Global character of disability phenomenon becomes a significant issue both for authorities and society a task to provide support towards disabled children, the youth, adults and their families. Forms of supporting actions should comprise financial, informative, psychological and rehabilitation aspect. Extremely important in such situation becomes the attitude of the society towards people with varied types of disorders.

\section{Disability}

Together with the growth of rehabilitation practice there have been visible changes in its terminology. Such expressions as "deficiency", "defect" or "handicap" have been removed from official use. Current reference of "disability" has successfully been replaced by the meaning of handicap, which was commonly in use throughout the $20^{\text {th }}$ century but especially after the Second World War. In those times the term of "disability" was rare in use or it was not found at all and it rather meant "restrictions in abilities" or "decreased ability". Recent years have brought domination in science and feature writing but also in colloquial consciousness of people by the meaning of "disability" as the one which has lower negative emotional balance (Kirenko, 2017, p. 9).

According to the definition given by the International Health Organization (1980) and following ones published at International Index of Injuries, Disabilities and Impairments, the term disability (in English - disability, in French - incapacite, invalidite, in German - Die Beschadigung, Invaliditat, in Russian niepolnociennost) is understood as a restriction resulting from inability to perform actions in the way which is perceived as natural for a man (Pilch, 2003, p. 647). 
„Disability” thus refers here to such a physical and psychical condition of an individual which either permanently or periodically makes for him difficult to perform life tasks and social roles according to legal and socially approved norms. Disability is a consequence of anatomical structure mechanism disorder or disturbing its physiological functions. Such condition may lead to an impairment which means loss of reluctance towards participating for an individual in social life.

While defining the term of disability it may become quite confusing because of close its relationship of functioning of the organism and psyche and variety of criteria used. Among most frequent criteria found are:

- psychological (subjective assessment of damage and related restrictions), social (range of essential support in social functioning: occasional, restricted, vast, visible features of damage, way of communicating etc.),

- educational (form of educational process organization: segregational, integrated, individual), clinical (etiology: field, inborn, gained, location e.g. sensor, intellectual, physical or somatic disability; range: single range, multi-range; degree: light, moderate, significant), legal (degree of activity which reveals in - play, learning process and work) (Siuta, 2005, p. 164-165).

Aleksandra Maciarz, based on the kind of dysfunctional ability, the degree of health loss among the disabled categorizes as the people who reveal:

- lowered sensor efficiency which is caused by the lack, damage or disorder sensor analyser functions (children who are: blind, visually impaired, death and profoundly death, with partial hearing loss and those with deficiencies in eye or hearing perception),

- lowered intellectual ability (children mentally ill and those with below average intelligence),

- lowered communication ability (children with varied speech disorders, autism),

- with lowered ability towards social functioning (children with behavior disorders, lack of social accommodation, those with disturbed nervous and emotional balance, disturbed mental health, endangered with drugs), 
- disturbed physical efficiency (these are the people with kinesthetic dysfunctions and kinesthetic disorders),

- lowered general psycho-physical efficiency which may classify disabled people due to somatic illnesses and caused by growth and weight anomaly,

- lowered psycho-physical efficiency due to care and educational neglect (cultural deprivation) (Maciarz, 1992, p. 10-11).

Such form of classification is still artificial and fixed because mostly a disabled person has a disturbed efficiency of varied kind and he requires extensive special care.

Disability to some extent leads to disintegration of all spheres of a man's life. The range of its results depends on the kind of disability, degree of particular organ disorder and the age of the disabled person. Disability influences functioning of an individual and his abilities to achieve life goals. A difficult social situation of the disabled is combined with occurrence of the so called barriers and hardships they have to face. These include physical barriers but those of architectural, urban planning, transportation, informative and technical are of major importance. Big problematic issues are social barriers which occur in legal regulations, customs and traditions, organization of education and spending leisure time. Social attitudes which are generally negative towards the disabled may also become an obstacle (Sadowska, 2004, p. 21).

\section{FORMAL AND LEGAL REGULATIONS}

The right to education due to its significant role was confirmed both in legal instruments of international and state importance. In Poland such a regulation is guaranteed at the highest, constitution level. According to its statement found in article 70 of the State Constitution "everyone has the right to education" act 1 , "education at state schools is provided free" act 2 and "public authorities guarantee common and equal access to education" act 4 (Constitution of the Republic of Poland). Regulation of the above right confirmed officially by the state constitution was admitted in numerous legal acts (Law Gazette 1991, no 95 position 425). According to article 1 point 5 of 
the Legal Act on the system of education dated on $7^{\text {th }}$ September 1991, each child with disability has the right to gain education at all types of schools, according to individual skills and abilities, growth and educational needs. In order to comply with the directives the authorities create supporting financial and organizational individual help programs. Moreover, children who demand special educational effects have to be provided with appropriate content, methods and organization of the teaching process, psychological and educational support together with special forms of didactic work and possibility to gain education at every type of school preferred. The act also introduces school duty regulation. Juridicature also stresses that according to the legislator principles a compulsory education is a guarantee towards equal right to education and it is entitled to each citizen (Pilich, 2013).

Disabled children and youth which demand special organization of education and work methods become subjected to special education treatment. It refers to the following groups of students:

- death and those with partial death loss,

- blind and those with weak eyesight,

- with kinesthetic disability, including those with aphasis,

- with intellectual disability in slight, moderate or significant degree,

- with autism disorders including Asperger syndrome,

- with combined disabilities, often labeled as "disabled students" (Law Gazette 2015, position 1113).

Legal regulation act by the Ministry of National Education on $24^{\text {th }}$ July 2015 determines education and upbringing process environment for disabled children and youth:

It points out to the fact that education, upbringing and care is conducted at:

- public nursery schools, nursery schools with integrated groups, integrated nursery schools, public nursery schools with special needs groups, special needs nursery schools and other forms of pre-school education;

- public schools, public schools with integrated groups, integrated, public schools with special needs groups, special schools, including those which prepare towards work; 
- youth care centres and youth socio-therapy centres;

- special care and education centres;

- centres which provide care of children and youth with deep mental illnesses, children and youth with mental illness and related disabilities in order to accomplish the duty of a year pre-school period, school duty and the duty of learning (Law Gazette 2015, position 1113).

Children and the youth whose health condition prevents from or significantly hinder pre-school or school attendance are subjected to compulsory a year period training in case of pre-school education and individual schooling. An official statement to apply special education or individual requirement of such year pre-school and individual teaching, but also that confirming revalidation and educational classes conducted in accordance with separate regulations can be determined by the adjudication panels which operate within services offered by public psychological and educational centres including special counseling centres. Such a statement determines advisable forms of special education considering disability type. The authorities of a local county office based on the disabled child parents' request, prior to be submitted with such a statement, makes a decision on appropriate form of education, considering the form of disability. Education for disabled students may be led until the end of a school year in the calendar year when the student reaches: the age of 18 - in case of primary school, until the age of 21 - in case of a middle school, the age of 23 - in case of a secondary school (Law Gazette 2015, position 1113).

Considering the above, the right towards educating is regarded nowadays as a universal solution which is entitled to anyone who "irrespective of one's features including health condition. In contemporary legal regulations there is no de facto legal possibility to deny access for a disabled person towards widely understood education as the only subject to make such a decision is the disabled himself. Best profits can be achieved by introducing inclusive education which allows disabled people for common functioning with able bodied environment, based on the same principles (a postulate of the least restricting environment)" (Sztumski, 2006, p. 156). Only in such system may guarantee equal access to education for disabled students. Moreover, in non- 
segregation forms of education disabled students acquire social competences at a higher level (Śleboda, 2012, p. 107). More and more it is postulated that schools should only focus on educating rather than specialistic rehabilitation which should be accomplished separately and run by other subjects (Lempart, 2012 , p. 79.) It has been proved that combining rehabilitation, resocialization and educating disabled children in one institution does not bring positive results in none of the mentioned spheres of life.

\section{ORGANIZATION, FORMS OF SUPPORTING ACTIONS AND HELP AIMED TOWARDS DISABLED CHILDREN AND THE YOUTH - CONCLUSIONS ON THE RESEARCH}

Students with disabilities who are categorized within an intellectual norm study by using the same coursebooks and follow the same school curriculum as their other peer colleagues while those with diagnosed mental disease follow a separate curriculum of general education. According to the regulations stated by the Ministry of State Education, disabled students are provided with state care by allowing for an individual to accomplish the education process and adapt the syllabus content, methods of work and organization of teaching adequate to students' psych-physical needs. For each student who is acknowledged to be specially educated an individual educational and therapeutic syllabus is designed which takes into consideration accomplishment of growth and educational needs. The syllabus is designed by the team in cooperation with the psychological and educational counseling centre (if required). The programme is considered to be carried out within the period of 30 days appointed in the official statement starting since the date such document was submitted to school authorities. Team work is coordinated by a class tutor and the meetings are held in accordance with the needs and the sessions can be attended by the student's parent or other parties (a doctor, psychologist, counselor or speech therapist) based on the parent request and following his approval.

The basis for disabled children and youth development are supporting actions which are aimed at making equal current deficiencies and decreasing restrictions but also building and creating environment surrounding to enable gain thorough experience, develop individual autonomy paying 
special attention to grow self-reliance and emotional resistance (Wiśniewska, 2010, p. 23-31). The process of support takes place only on condition that it considers significant features of natural growth changes: their relative permanence and position in a sequence of growth processes referred to particular spheres (Kielar-Turska, 2013, p. 20).

Regulations concerning the environment needed for early stage support development of a child are defined in the directive of the Ministry of State Education and they point that the main aim of such activities and supporting actions is to activate psycho-kinesthetic and social development of an individual. Activities aimed towards supporting development may be led both at a nursery and following primary school, including special care centres but also public and unpublic psychological and educational counseling centres but also a specialistic centre, provided that such an institution is equipped with appropriate teaching materials and equipment (Law Gazette No 23, position 133).

\section{RESULTS RESEARCH}

Supporting disabled children and youth plays an exceptional role in prevention and therapeutic work and significantly determines the process of further development of an individual. In order to know and evaluate effectiveness of forms of support aimed at disabled students' development it was at the turn of January and February in 2018 when a quality research (based on interviews) was conducted among the group of 32 teachers employed at schools with integrated classes over the area of Lublin region.

In opinion of the teachers concerning the issue of supporting development of students with disabilities, such support becomes a reinforcement of what is and is believed to be useful and it means searching for new opportunities and combining them with the existing ones. As a fundamental supporting issue perceived by the respondents is to learn and make a use of a particular student's strengths. That means it should take into account age of an individual, symptoms of the disorders, daily family life, comprise somatic, intellectual, motricity, social and emotional sphere but also consider student's individual needs and abilities. Multi-specialistic, complex and coordinated help means also simultaneous, complementary with each other medical, psychological, educational and speech therapy actions aimed towards creating optimal 
conditions to provide development of a disabled child and on the other hand prevent negative effects of growth deficits.

Special attention the respondents paid to the necessity of considering individual students' features both in educational and teaching actions. Unfortunately, it becomes a frequent problem at school due to a common and group character of educational centres. Some of the school failures result from the lack of consideration individual features and predispositions of their students.

The researched teachers while referring to their infrequently long lasting experience in their work with disabled students, they undermine that the process of teaching disabled students in one school together with their able bodied peers should be accomplished prior to appropriately provided conditions which means: common decision of the teaching staff, an agreement made by the students' parents and agreement of the authority office where particular school is subjected to. At the same time the respondents stress that integration is a long lasting and complicated process where an important role is paid to able bodied students by showing tolerance and help addressed to their disabled peers. Moreover, integrated teaching becomes effective provided that the educational process is run by two teachers' simultaneous work, supported additionally by other specialists. Thus the responded teachers clearly stressed the need to employ staff with special educational teaching skills and specialists to run revalidation classes both at integrated schools and generally offered public schools with integrated classes.

In opinion of the teachers, supporting actions aimed at disabled children and youth become significantly reasonable when they are based on appropriate previous diagnosis which means understanding. Quality of educational procedure is conditioned by appropriate recognition (diagnosis) of the student, supporting his development (by individual educational programme) and finally effectiveness which means achieving a success in a particular dimension. Complete diagnosis according to the researched teachers should be based on: observing the student's behavior in task solving and social situations, talks with the student, interviews with the parents, analysis of the student's work, diagnostic research e.g. tests and a detailed and close analysis of the documentation. 
The responded teachers agreeably admitted that support directed at a disabled child has larger chance to bring success once it is possible to cover all the aspects of its functioning including: restrictions, strong and weak activity areas and development strengths. Thus, according to the interviewed teachers tasks which are included in the school curriculum should: be included in the sphere of closest student development, practice functions which are mostly endangered, make a use of strong points, bring enjoyment and attractiveness, encourage towards gaining knowledge, consider the principle of "little steps", enable to achieve success (even of little importance) and they cannot be neither too easy nor too difficult. Moreover, appropriately designed programme of supporting actions should include all development spheres such as perceptional, motoric, cognitive, social and emotional.

In opinion of the teachers, possessing such knowledge about a student, gathered during educational diagnosis it is possible to do a complex evaluation of a student's development. Knowing initial condition of a student's development it is possible to: assess his achievements even though they are of small significance and do not comply with the curriculum requirements, better evaluate his efforts which the student puts in gaining knowledge and skills, better understand his talents or difficulties and develop deeper emotional links with the student.

\section{Conclusions}

Apart from such forms of supporting a disabled student's development as: psycho-corrective influence (decreasing growth of psychical disorders through educating and therapy); psychotherapy and behavior modification; re-education (regaining previously acquired skills); revalidation and education classes (regaining efficiency) the researched teachers pointed to possibility in supporting student's development and involving him in educational actions with the use of special instruments and devices. In opinion of the teachers supporting technology (or in English assistive technology - AT) offering a wide range of tools, devices (software, interface, tablets, and specialistic applications, computer peripheries, communicators, systems of surrounding control and others), adds to the improvement or support of disabled student functioning. It gives the feeling of occurrence and influence the situation and 
actions: both referred to obedience of the teacher's tasks and actions which result from class project accomplishment, including personal activity, own exploration and developing individual's interests.

In opinion of the researched teachers an essential and major task for those who are engaged in the process of supporting development of disabled children and youth is an acceptance of the individual and extended help aimed at his further achievement and development in spheres comprising intellectual, emotional, social and physical but also performing social roles, the feeling of identity and attitude towards other people. Appropriate evaluation of such abilities and skills of the disabled student becomes an essential part in education direction together with adequate tasks to be fulfilled.

The results of the research carried out under the research topic No. 623/18/S were financed from the grant for science, awarded by the Ministry of Science and Higher Education.

\section{References:}

Kielar-Turska, M. (2003). Analiza pola semantycznego terminów związanych ze wspomaganiem rozwoju. W: B. Kaja (red.), Wspomaganie rozwoju. Psychostymulacja i psychokorekcja. Bydgoszcz: Wydawnictwo WSP, s. 11-22. [Translation: Analysis of semantic field terms referred to supporting development. in: Development support. Psycho-stimulation and psycho-correction, edited by B. Kaja, Bydgoszcz: WSP Publisher, p. 11-22.] ISBN 8370964923.

Kirenko, J. (2007). Indywidualna i społeczna percepcja niepełnosprawności. Lublin: Uniwersytet Marii Curie-Skłodowskiej, s. 9. [Translation: Individual and social perception of disability. Lublin: University of Maria Curie-Skłodowska Publisher, p. 9]. ISBN 9788322727799.

Konstytucja Rzeczypospolitej Polskiej z dnia 2 kwietnia 1997 r. art. 70, pkt. 1, ust. 1. [Translation: Constitution of the Republic of Poland on 2nd April, 1997].

Lempart, M. (2012). Wybrane problemy orzecznictwa $w$ zakresie potrzeby kształcenia specjalnego. „Biuletyn Rzecznika Praw Obywatelskich” nr 7, s. 79. [Translation: Selected problems of pronouncing on the need of special education. „Bulletin of the Civil Rights Spokesman” 2012, no 7, p. 79]. ISSN 0860-7958.

Maciarz, A. (1992). Uczniowie niepetnosprawni w szkole powszechnej. Warszawa: WSiP, s. 10-11. [Translation: Disabled students in a public school. Warsaw: WSiP Publisher, p. 10-11]. ISBN 8302038385. 
Pilch, T. (2003). Encyklopedia pedagogiczna XXI wieku, t. III. Warszawa: Wyd. Akademickie „Żak”, s. 646-647. [Translation: Encyclopedia of education of the $20^{\text {th }}$ century. Vol. III, Warsaw: „Żak” Academic Publisher, p. 646-647]. ISBN 8389501244.

Pilich, M. (2013). Ustawa o systemie oświaty. Komentarz, Warszawa: LEX nr 154028. [Translation: Parliament act on education. Comment, LEX 2013, no. 154028]. ISBN 9788326444791.

Rozporzadzenie Ministra Edukacji Narodowej z dnia 24 lipca 2015 r. w sprawie warunków organizowania kształcenia, wychowania i opieki dla dzieci i młodzieży niepetnosprawnych, niedostosowanych społecznie i zagrożonych niedostosowaniem społecznym, Dz.U. 2015 poz. 1113. [Translation: Government order by the Minister of National Education passed on 24th July 2015 about conditions to organize education, upbringing and care of the disabled youth, socially unadjusted and endangered with social adjustment, ("Law Gazette" 2015, position 1113].

Rozporzadzenie Ministra Edukacji Narodowej z 3 lutego 2009 r.w sprawie organizowania wczesnego wspomagania rozwoju dzieci, Dz.U. nr 23, poz. 133. [Translation: Government order by the Minister of National Education passed on 3rd February 2009 on the issue of organizing early support of a child development, ("Law Gazette" No 23, position 133].

Sadowska, L. (red.) (2004). Neurofizjologiczne metody usprawniania dzieci z zaburzeniami rozwoju. Wrocław: Wyd. AWF, s. 21. [Translation: Neuro-physiological methods of improvement children's with growth disorders. Wroclaw: AWF Publisher, p. 21]. ISBN 8389156245.

Siuta, J. (2005). Słownik psychologii. Kraków: Wyd. Zielona Sowa, s. 164-165 [Translation: The dictionary of psychology. Cracow: Green Owl Publisher, p. 164-165]. ISBN 8374350199.

Szumski, G. (2006). Integracyjne kształcenie niepełnosprawnych, Warszawa: PWN, s. 156. [Translation: Integrated education of disabled. Warsaw: PWN, p. 156]. ISBN 9788301147112.

Śleboda, R. Kierunek i poziom wykształcenia oraz aktywność zawodowa osób $z$ niepełnosprawnością (2012). „Niepełnosprawność - zagadnienia, problemy, rozwiązania" nr 2, s. 107. [Translation: Directions and level of education, professional activity of people with disabilities, „Disability - issues, problems, solutions” no. 2/2012, p. 107]. ISSN 2084-7734.

Ustawa o systemie oświaty z 7 września 1991 r. (Dz.U z 1996 r. nr 67, poz. 329 z późniejszymi zmianami). [Translation: Act of Parliament about the system of education passed on $7^{\text {th }}$ September 1991 r., "Law Gazette" 1991, no 95, position 425]. 
Ustawa z dnia 14 grudnia 2016 r. Prawo oświatowe (Dz.U. z 2018 r. poz. 996, 1000 i 1290) ogłoszono dnia 24 maja 2018 r. obowiązuje od dnia 1 września 2017r. [Translation: Act of Parliament passed on 14th December 2016. Educational Law ("Law Gazette" 2018, position 996, 1000 and 1290) announced on 24th May 2018 implemented from $1^{\text {st }}$ September 2017].

Wiśniewska, M. (2010), Wspomaganie rozwoju dziecka z niepetnosprawnościa intelektualna. Kraków: Oficyna Wydawnicza Impuls, s. 23-31. [Translation: Supporting child's development with mental disability. Cracow: Impuls Publisher, p. 23-31]. ISBN 9788375874143. 
